\title{
The role of inflammation and antiinflammation therapies in keratoconjunctivitis sicca
}

\author{
Koray Gumus' \\ Dwight H Cavanagh² \\ 'Department of Ophthalmology, \\ Erciyes University School of Medicine, \\ Kayseri, Turkey; ${ }^{2}$ Department \\ of Ophthalmology, The University \\ of Texas Southwestern Medical \\ Center, Dallas, Texas, USA
}

\begin{abstract}
Purpose: To review and integrate recent advances in identifying the role of inflammation in the pathogenesis of dry eye conditions and the biological rationale and practical clinical aspects of newer, antiinflammatory theories.

Methods: A comprehensive literature survey.

Results and conclusion: Keratoconjunctivitis Sicca (KCS) is a multifactorial and complex disorder in which ocular surface inflammations play a central role. Identification of specific CD4-T-Cell pathways and the recent recognition of targeting of alpha-fodrin suggest a case for novel new therapeutic aspects such as anti-CD4 monoclonal antibodies, systemic linoleic and gamma-linolenic acids, and omega- 6 essential fatty acids. Replacement of tear volume with nonpreserved wetting agents and standard typical antiinflammatory corticosteroid and/or cyclosporine A continues to be central current conventional therapy for KCS.
\end{abstract}

Keywords: dry eye, keratoconjunctivitis sicca, antiinflammatory therapy

Dry eye disease or keratoconjunctivitis sicca (KCS) is a common disorder which refers to a spectrum of ocular surface diseases with multiple etiologies. ${ }^{1} \mathrm{KCS}$ is associated with symptoms of ocular discomfort such as burning, sense of dryness, foreign body sensation, ocular pain, and is sometimes associated with photophobia, blurred vision, visual fatigue, and sight-threatening corneal complications in severe cases. ${ }^{2,3}$ Epidemiologic studies have stated that more than $6 \%$ of the population complains of dry eye symptoms, and this ratio increases to $15 \%$ over the age of $65 .{ }^{4-6}$ Most of the studies have also found an increasing prevalence with aging and greater prevalence among women due to the hormonal status. ${ }^{4,6,7}$

Pathogenesis of KCS has not been completely clarified. Even though KCS has been thought of classically and basically as a condition of tear deficiency, whether caused by decreased lacrimation or excessive evaporation, it is a complex disorder. Many clinicopathological entities involving tear film, lacrimal glands, eyelids, and a wide spectrum of ocular surface cells, including epithelial, inflammatory, immune, and goblet cells may play a role in its pathogenesis. ${ }^{2,8}$

Over the past years, as a result of numerous studies, new concepts of pathogenesis have shown that KCS seems to be caused by inflammation mediated by T-cell lymphocytes. ${ }^{9-11}$ This finding has also been augmented by the studies investigating the role of antiinflammatory therapies. For instance, the treatment of KCS gained a new dimension with the approval of topical 0.05\% cyclosporine A (Restasis) (Allergan, Inc., package insert for Restasis) by the US Food and Drug Administration. Consequently, because of the increasing importance of the role of inflammation and the use of cyclosporine eye drops, the goal of this review article is to provide the readers with an overview of 
the role of inflammation and also to discuss antiinflammatory therapies such as topical cyclosporine in KCS.

\section{Inflammaton in dry eye Lacrimal gland inflammation}

The lacrimal gland that secretes proteins, electrolytes and water is the main contributor to the aqueous layer of the tear film. With these properties, it helps to nourish and protect the ocular surface. Lacrimal gland secretion is primarily under neural control, which is achieved through a neural reflex arc functioning as an integrated or "functional unit". ${ }^{8,12}$ Stimuli to the ocular surface activate afferent sensory nerves in the cornea and conjunctiva. This stimulus then goes to the central nervous system in the area of pons via the ophthalmic branch of the trigeminal nerve. In the end, it activates efferent nerves consisting of parasympathetic fibers which travel in the facial nerve and sympathetic fibers emerging from the paraspinal sympathetic chain to stimulate secretion. ${ }^{8,12}$ As mentioned above, it has been suggested that KCS is an inflammatory disorder that affects both the ocular surface and the lacrimal gland. For instance, in some clinical disorders such as Sjögren's syndrome (SS), graft versus host disease, sarcoidosis and as a result of aging the lacrimal gland may become an important target of the immune system and show signs of inflammation. ${ }^{12}$ The presence of focal lymphocytic infiltrates and increased production of proinflammatory cytokines are the characteristic findings of lacrimal gland inflammation. ${ }^{12}$

Sjögren's syndrome, is most likely to affect females, and overall is a systemic and multifactorial inflammatory disease affecting primarily the lacrimal and salivary glands, resulting in dry mouth and dry eyes. ${ }^{12,13}$ It may be seen as a primary disease or can be associated with other autoimmune diseases such as rheumatoid arthritis, systemic lupus erythematosus, or systemic sclerosis. ${ }^{13}$ The diagnosis of SS is often difficult, especially in the early stages of the disease. At this point, circulating antibodies presumably produced by $B$ cells are a characteristic hallmark of SS and may be useful for the diagnosis. ${ }^{14}$ Apart from the most commonly detected auto-antibodies such as Ro/SSA and $\mathrm{La} / \mathrm{SSB},{ }^{15}$ which are directed against ribonucleoproteins and are included in the European-American Diagnostic Criteria for primary SS, there are also other autoantibodies against $\alpha$-fodrin and $M_{3}$ muscarinic receptors. ${ }^{16-18}$ The presence of autoantibodies Ro/SSA and La/SSB was found to be generally associated with a longer disease duration, increased frequency of nonexocrine manifestations and a higher intensity of lymphocytic infiltrates invading the minor salivary glands. ${ }^{19}$ Recent case reports and some research have shown that autoantibodies against $\alpha$-fodrin may be used in the diagnosis and may also be considered as an activation marker of SS with dry eye. ${ }^{20-22}$ Interestingly, it has been determined that the positive anti- $\alpha$-fodrin antibody might support the diagnosis of SS even with negative results of anti-Ro/SSA and anti$\mathrm{La} / \mathrm{SSB} .{ }^{22}$ In addition to the presence of these antibodies in serum, anti-Ro/SSA and anti-La/SSB antibodies may be present in the tear fluid of some patients with SS, and their presence in serum or tear fluid may be a clinical marker for the severity of KCS. ${ }^{23}$ Circulating autoantibodies against muscarinic acetylcholine receptors (mAChRs) have also been investigated, and it has been emphasized that it could be a new marker to differentiate SS dry eye from non-SS dry eye. ${ }^{24}$ In another study, it has been stressed that besides these antibodies' contribution to sicca symptoms, autoantibodies acting as antagonists at M3-muscarinic receptors might explain associated features of autonomic dysfunction in some SS patients. ${ }^{25}$

Apart from autoantibodies, pro-inflammatory cytokines such as interleukin-1 $\beta$ (IL-1 $\beta$ ) seem to be very crucial in the pathophysiological understanding of $\mathrm{KCS} .{ }^{26}$ For instance, IL-1 $\beta$ may cause a marked increase in nitric oxide (NO) production via induction of iNOS in lacrimal gland epithelial cells, and hence overproduction of NO may be a factor in lacrimal gland cell death in KCS. ${ }^{26}$ Moreover, inhibitors of iNOS or IL-1 receptor may be beneficial for controlling lacrimal gland inflammation ${ }^{26}$ and may help us to control the dry eye symptoms in SS patients. In an animal model investigating the relationship between interleukin-1 $\beta$-induced NO production and sex-hormones, it has been reported that androgens and estrogens can downregulate cytokinemediated responses in lacrimal gland acinar cells that are important for the maintenance of ocular surface protection and thereby may play an important role in regulating inflammatory responses in the eye. ${ }^{27}$ This finding may help us to explain the increasing prevalence of dry eye symptoms in postmenopausal women. In another study supporting the possible contribution of above-mentioned iNOS pathway both to the pathogenesis and to the treatment of KCS, the role of c-Jun NH2-terminal kinase (JNK) in IL-1 $\beta$-mediated inhibition of lacrimal gland secretion and tear production was explained, and it was documented that treatment for 7 days with SP600125 that is the inhibitor of JNK increased tear production in a murine model of SS dry eye. ${ }^{28}$

Another important disorder based on inflammatory etiology and resulting in dry eye symptoms is sarcoidosis which is a multisystemic disorder of unknown etiology and characterized by the presence of noncaseating granulomas 
in multiple organs such as lungs, spleen, liver, lymph nodes, skin, and salivary and lacrimal glands. ${ }^{12,29,30}$ Because patients with sarcoidosis may complain about dry eye and dry mouth as occur in SS, it may be very difficult to differentiate between the two diseases.

The lacrimal gland is not the only effected site for sarcoidosis but the orbit, lacrimal sac, eyelid, etc can be involved as well. ${ }^{31}$ It as been documented that tear film deficiencies are common in sarcoidosis, even though clinical symptoms are present. In the same study, it was emphasized that deficiency of mucin and lipid layers may also accompany aqueous layer deficiency. ${ }^{32}$

In sarcoidosis, it has been thought that exposure to an environmental antigen in a genetically susceptible individual may trigger an immunologic response in many organs, as mentioned above. ${ }^{33}$ In the pathogenesis of granuloma formation, a complex interaction is thought to occur between many cell types, cytokines, and chemokines. ${ }^{34}$ The main immunopathologic characteristic of involved organs is the accumulation of activated lymphocytes, predominantly $\mathrm{T}$ helper cells, expressing the Th1 phenotype and monocytes/macrophages. Chemokines are also required for the extravasation of leukocytes to the inflammation site. In one study to determine which chemokines are augmented in the serum of patients with active ocular sarcoidosis, serum levels of CXCL9 and CXCL10 were found to be elevated markedly in the patients with ocular sarcoidosis and correlated with ocular disease activity and angiotensin-converting enzyme (ACE) level. ${ }^{35} \mathrm{In}$ another study, increased circulating IL-12 p40, which is one of the most important cytokines for promoting Th1 reaction, was found to be an important systemic marker for disease activity, and it has been emphasized that it may reflect the increased interaction between IL-12 and its ligand IL-12R in sarcoid lesions of involved organs. ${ }^{36}$ Another important finding is the increased levels of proinflammatory cytokines such as tumor necrosis factor- $\alpha(\mathrm{TNF} \alpha)$ in sarcoidosis. ${ }^{37,38}$ TNF $\alpha$ exerts its effect by binding to specific cell surface receptors such as membrane TNF receptor (mTNFR)-1 and mTNFR-2, and can be blocked by soluble TNF receptor (sTNFR)-1 and sTNFR-2. ${ }^{39}$ Because of these properties, in the past several years, both TNF $\alpha$ monoclonal antibody and soluble TNF receptor have been investigated for the treatment of sarcoidosis, and ocular involvement as well. The details of treatment strategies for dry eye are explained in the second section of this review.

Chronic graft versus host disease (GVHD) is an important entity for patients undergoing hematopoietic stem cell transplantation because of the hematologic malignancies, induced by the reaction of donor $\mathrm{T}$ cells to recipient histoincompatible antigens. ${ }^{40,41}$

The importance of GVHD for the ophthalmologist comes from its ocular complications. Severe dry eye is one of the most frequent ocular complications of GVHD. ${ }^{42}$ Apart from the importance of CD4 and CD8 (+) lymphocytes which were found primarily in the periductal areas of the lacrimal glands in patients with chronic GVHD, one of the most important additional findings is marked fibrosis of the glandular interstitium and an increased number of CD34 (+) stromal fibroblasts. ${ }^{43}$ Proinflammatory cytokines also play a critical role in the pathogenesis of GVHD similar to those which occur in all immunologic events such as SS. ${ }^{44}$

In most of the studies, the prevalence and/or incidence of KCS were found to be higher in older patients. ${ }^{45,46}$ This finding has also motivated many researchers to investigate and clarify the underlying pathophysiology of aging on lacrimal glands. For instance, in one of these studies, an animal model, aiming to investigate the effect of aging on lacrimal gland structure, innervation and function using BALB/c mice at different ages, it has been concluded that notable changes occurring with aging are the increased accumulation of lipofuscin-like inclusions, chronic inflammation and functional alterations including decreased acetylcholine release and protein secretion. ${ }^{47}$ In addition to these findings such as chronic inflammation and mast cell infiltration to the lacrimal gland occurring with aging, morphological and functional changes in acini has also occurred resulting in reduction or an inability to synthesize and to secrete protein from the glands of aged animals as compared to the glands of young rats. ${ }^{48}$

\section{Ocular surface inflammation}

In KCS patients, ocular surface inflammation can be evaluated as both the cause and the consequence of cell damage. ${ }^{49}$ Whether it is a cause or a consequence, it is well known that a dangerous vicious circle occurs between ocular inflammation and dry eye, and in turn may lead to sight-threatening complications. There are numerous factors that may contribute to the formation of ocular surface inflammation such as desiccating stress, ${ }^{50}$ hyperosmolarity, ${ }^{51}$ proinflammatory cytokines released from the lacrimal glands, ${ }^{12}$ and blinking abnormalities. ${ }^{52}$

The role of inflammatory cytokines and matrix metalloproteinases (MMPs) in the pathogenesis of dry eye seems to be very important for both the easier understanding of KCS and for the discovery of new therapeutic agents. IL-1 is one of the most studied cytokines accompanying KCS. 
For instance, in one study by Solomon and colleagues it was documented that an increase in the proinflammatory forms of IL-1 (IL- $1 \alpha$ and mature IL- $1 \beta$ ) and a decrease in the biologically inactive precursor IL-1 $\beta$ were found in tear fluid in dry eye. ${ }^{53}$ Moreover, the source of the increased levels of IL-1 in the tear fluid of patients with KCS was thought to be the conjunctival epithelium. ${ }^{53}$ Recently, reactive nitrogen species have just been investigated in dry eye and it has been suggested that they might be involved in the pathogenesis or self-propagation of autoimmune dry eye (SS). ${ }^{54}$ In the same study, IL-1 $\beta$, IL-6, IL-8, TNF $\alpha$ were also investigated and the staining of these cytokines was found to be more in dry eyes in contrast to normal eyes. ${ }^{54}$

The response of cells to extracellular stimuli such as ocular surface stress including increased tear film and ultraviolet light exposure is mediated in part by a number of intracellular kinase and phosphatase enzymes. ${ }^{55,56}$ Stress-activated protein kinases have been identified for this purpose. ${ }^{56}$ And it has been documented that activation of these stress pathways results in transcription of stress related genes, including inflammatory cytokines such as IL-1 and TNF- $\alpha$ and MMPs, mainly MMP-9. ${ }^{56}$ In another study, mitogen-activated protein kinases (MAPKs) were found to stimulate the production of inflammatory cytokines and MMPs including IL- $\beta$, TNF- $\alpha$, and MMP-9. 57

As mentioned above, hyperosmolarity is one of the factors contributing to ocular surface inflammation. In one study investigating whether exposure of human limbal epithelial cells to hyperosmotic stress activates the MAPK pathways and induces production of pro-inflammatory cytokines, it was concluded that hyperosmolarity induces inflammation in human limbal epithelial cells by increasing expression and production of pro-inflammatory cytokines and chemokines such as IL-1 $\beta$, TNF- $\alpha$, and the C-X-C chemokine IL- 8 , and that this process appears to be mediated through activation of the c-Jun N-terminal kinases (JNK) and extracellularregulated kinase (ERK) MAPK signaling pathways. ${ }^{58}$ All these factors should not only be considered as important factors in the pathogenesis of KCS but also they should be kept in mind when discussing the treatment strategies. For instance, the efficacy of corticosteroid and doxycycline which are mostly used for treating ocular surface diseases may be explained by their ability to suppress JNK and ERK signaling activation and inflammatory mediator production in the limbal epithelium..$^{58,59}$

One of the most important components of the ocular surface is highly glycosylated hydrophilic glycoproteins, the mucins, which help a tear film to be held in place by wet-surfaced, stratified corneal and conjunctival epithelia. ${ }^{60,61}$ They are expressed by ocular surface epithelia and vital to the maintenance of healthy epithelial surfaces including the ocular surface. ${ }^{60,61}$ Mucins that have been detected in the eye including MUC1, MUC2, MUC4, MUC5AC, MUC 7, MUC13, MUC15, MUC16, and MUC17 are classified as transmembrane and secretory. ${ }^{1}$ While conjunctival goblet cells secrete the large gel-forming mucin $M U C 5 A C$, and lacrimal gland epithelia secrete the small soluble mucin $M U C 7$, apical cells of the stratified epithelium of both corneal and conjunctival epithelium express at least three membraneassociated mucins including MUCs 1, 4, and 16. ${ }^{60,61}$ The membrane-associated mucins form the glycocalyx, which provides an important continuous barrier across the surface of the eye for preventing pathogen penetrance and has signaling capabilities that influence epithelial activity. ${ }^{60,61}$ As explained above, because of their importance, alteration of either mucin distribution or mucin glycosylation on the surfaces of apical epithelial cells are also involved in the pathogenesis of dry eye. ${ }^{62}$ For instance, while MUC5AC expression is reduced in SS, glycosylation of MUC16 appears to be altered in non-SS dry eye patients. ${ }^{61}$

Other important factors that might contribute to ocular surface inflammation and in turn result in dry eye are the loss of peptide growth factors (ie, epidermal growth factor) and vitamin A which are necessary for cellular proliferation, migration, normal differentiation, immune modulation, and ocular wound healing. 1,63,64 However, further investigations are needed to clarify these molecules' exact roles in the pathogenesis of ocular surface inflammation and also $\mathrm{KCS}$.

\section{Blepharitis, meibomian gland dysfunction, and ocular allergy}

Because of both anatomic proximity and functional interactions between lids and ocular surface, it becomes unavoidable not to consider dry eye symptoms in many of the cases with associated blepharitis, meibomian gland dysfunction, and ocular allergy. There is a mutual causeeffect relationship between these disorders. For instance, while blepharitis and/or meibomian gland dysfunction may contribute to KCS by two mechanisms including lipid layer alteration in tear film leading to evaporative dry eye symptoms and directly effect ocular surface inflammation by providing antigenic and proinflammatory cytokine substances, on the other hand, KCS may increase the susceptibility to blepharitis due to the decreased tear antimicrobial activity and tear clearance. , $^{1,65,66}$ 
During practical clinical applications, practitioners may sometimes face difficulties in differentiating ocular allergy and KCS due to the number of overlapping symptoms. Actually, not only the symptoms are similar, but also there are some similarities between these two disorders in respect of molecular mechanisms involved in the pathogenesis of these disorders. In particular, it has been documented that allergic conjunctivitis deteriorates normal tear film structures with inflammatory basis and in turn predispose a patient to dry eye. ${ }^{67}$ Moreover, eye rubbing related to ocular allergy and severe blepharitis may also disrupt the epithelium and induces significant alteration in the inflammatory cell infiltrate of the conjunctiva, and thereby influences the course of ocular surface diseases such as KCS by worsening the inflammation on the ocular surface..$^{68}$

The association between lacrimal gland dysfunction, ocular surface inflammation, and KCS is summarized in Figure 1.

\section{Antiinflammatory therapy strategies in dry eye}

Antiinflammatory therapy and some new novel medications have been discussed more comprehensively since numerous evidences showing the role of inflammation in the pathogenesis of KCS were established. As mentioned above, KCS tends to be accompanied by underlying inflammation; therefore the use of antiinflammatory medications might prove beneficial for both the subjective and objective complaints of dry eye. In this section of the review, we present up-to date antiinflammatory therapy strategies discussing both well-known and newly designed current novel medications.

\section{Topical $0.05 \%$ cyclosporine}

As a result of numerous research projects investigating how to cope with an underlying inflammation in cases with KCS, a new therapy, cyclosporine (CsA) $0.05 \%$ ophthalmic emulsion (Restasis) has been approved by the Unite States

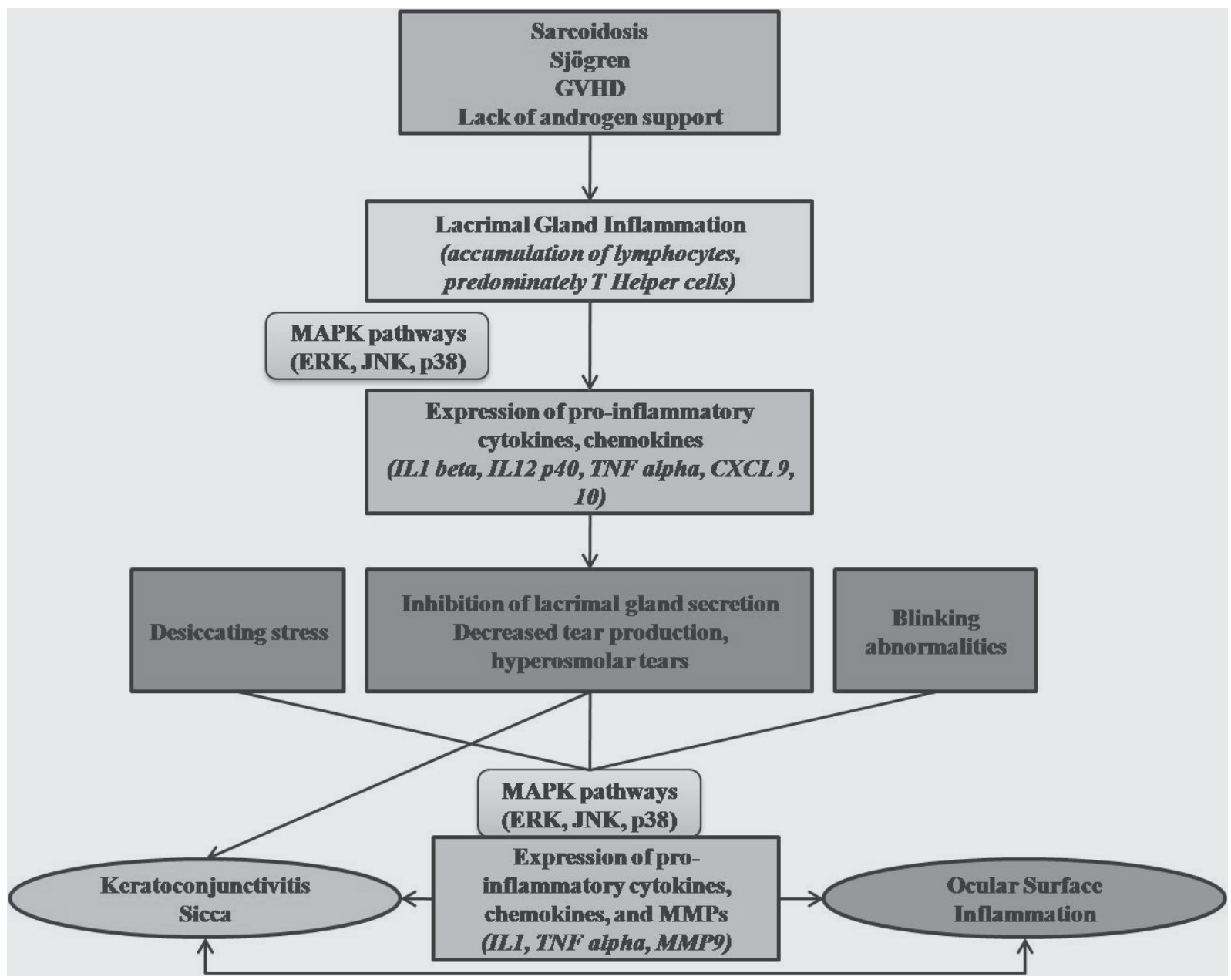

Figure I This schematic figure reveals the association of ocular surface inflammation, lacrimal gland dysfunction, and keratoconjunctivitis sicca.

Abbreviations: MMP, matrix metalloproteinase; JNK, c-Jun $\mathrm{NH}_{2}$ terminal kinase; MAPKs, mitogen activated protein kinases; ERK, extracellular-signal regulated kinase; IL, interleukin;TNF, tumor necrosis factor; $\mathrm{CXCL}$, chemokine ligand. 
Food and Drug Administration to increase tear production in moderate to severe cases. In fact, CsA has been used as an immune modulating drug to prevent tissue or organ rejections after transplantations. Moreover, acquaintanceship between CsA and ocular disorders is based on the past. For instance, systemic CsA has been used in the treatment of various autoimmune diseases with ocular involvement. ${ }^{69}$ In ophthalmology, topically applied CsA was first used to inhibit experimental corneal allograft reaction; ${ }^{70}$ later it became an important agent that can be used in various ocular surface inflammations. $^{71,72}$

CsA, which is a fungal derived peptide, has potent immunosuppressive properties which prevent the transcription of cytokine genes in activated T cells. ${ }^{73}$ At this point, the question is what kind of characteristics makes CsA one of the most highly potent immunosuppressive drugs? In order to explain this, we have to know its mechanisms. CsA first binds to cyclophilin in a cytoplasm and makes a complex, and then inhibits the phosphatase activity of calcineurin which is so crucial for nuclear translocation and activation of the nuclear factor of activated T cells (NFAT) transcription factors. ${ }^{73}$ In an in vitro study that evaluated the modulatory effects of dexamethasone and CsA on the production of cytokines and chemokines by human corneal cells in vitro following stimulation by the pro-inflammatory cytokine after IL-1 $\beta$, CsA was not found to have direct immunosuppressive effects on human corneal epithelial cells and human corneal fibroblasts. ${ }^{74}$ This finding also suggests that topical CsA's clinically observed immunosuppressive effects are mainly mediated by the immune cells. ${ }^{74}$ Moreover, CsA also blocks the activation of JNK and p38 signaling pathways during T-cell activation. ${ }^{75}$ Besides these properties, it has also been suggested that CsA has the potential to increase tear-fluid secretion by releasing a neurotransmitter such as substance $\mathrm{P}$ from sensory nerve endings which interact with the parasympathetic nerves. ${ }^{76}$

Because of its powerful immune modulator effect described above, $0.05 \%$ CsA ophthalmic emulsion has been used widely not only in KCS cases but also in other various ocular surface diseases including vernal keratoconjunctivitis, atopic keratoconjunctivitis, Thygeson's superficial punctuate keratitis, noninfectious keratitis, ligneous conjunctivitis, lichen planus, and superior limbic keratoconjunctivitis. ${ }^{77}$

Prior to the achievements accomplished in the pathogenetic of dry eye, the general approach to treating dry eye cases was to lubricate the ocular surface by using artificial tear drops, ointments, and pomades without treating the underlying pathogenetic factor such as inflammation. However, use of antiinflammatory agents is showing a gradual increase in the treatment of KCS due to the fact that several clinical studies have shown topical CsA to improve both objective and subjective sign of KCS. ${ }^{78-81}$ For instance, in one study investigating the effect of $0.05 \%$ topical CsA on the ocular surface and tear functions in cases with chronic GVHD, it was suggested that CsA may improve the ocular surface and tear functions by decreasing inflammation, increasing goblet cell density and MUC5AC mRNA expression. ${ }^{82}$ In another study comparing the efficacy of topical CsA, punctual occlusion, and a combination for the treatment of dry eye, addressed the finding that these three regimens revealed improvement in examination parameters but at the same time a combination therapy (punctual occlusion and topical CsA) was found to be superior to plugs alone in decreasing artificial tear use at 6 months. ${ }^{83}$ However, possible adverse effects of punctual occlusion on lacrimal gland functions should not be forgotten. For instance, Yen and colleagues concluded that temporary punctual occlusion in normal subjects decreases tear production and ocular surface sensation because of the damage of ocular surface/lacrimal gland interaction. ${ }^{84}$ Similar findings were documented by another study by Pflugfelder and colleagues. ${ }^{85}$ In that study, they suggested that punctual occlusion may worsen dry eye parameters, and premature occlusion may harm the biofeedback loop to the ocular surface enervation. ${ }^{85}$ In addition to these findings, inserting a plug may result in keeping inflammatory cells, cytokines, chemokines, and MMPs on the ocular surface. However, it does not mean that punctual plugs should not be used in patients with KCS. In selected cases, especially after inflammation is under controlled, punctual plugs are still important parts of the treatment in patients with severe KCS.

Kunert and colleagues also supported the positive effect of topical CsA on lymphocyte activation within the conjunctiva of Sjögren's and non-Sjögren's dry eye patients. ${ }^{10}$ According to that study, a statistically significant decrease in the number of cells expressing the lymphocyte activation markers CD11a and HLA DR was found in the case group who took topical $0.05 \% \mathrm{CsA} .{ }^{10}$ Another similar study has demonstrated a significant decrease in IL- 6 in the conjunctival epithelium of SS patients treated with $0.05 \% \mathrm{CsA}$ for 6 months. ${ }^{86}$ In the same study, it was also concluded that IL-6 was not different from the baseline at 3 months. ${ }^{86}$ Based on this last finding, it would not be an incorrect conclusion to suggest that the therapy duration for $\mathrm{CsA}$ in $\mathrm{KCS}$ should be at least six months. ${ }^{86}$ 


\section{Corticosteroid therapy}

Corticosteroid therapy which has been used in medicine for many years is also preferred in many ocular diseases with underlying inflammatory processes such as KCS. As was mentioned in the previous section, inflammation seems to be a key pathogenic factor for dry eye, and because of that, some patients may continue to complain of eye irritation despite adequate aqueous enhancement therapies without any antiinflammatory drugs. Numerous studies have concluded topical or systemic corticosteroid therapy may have several benefits in the treatment of moderate to severe dry eyes. ${ }^{59,87,88}$ For instance, in one study reviewing the efficacy and side effects of topical nonpreserved corticosteroid therapy for treatment of severe KCS with SS, topical nonpreserved methylprednisolone was found to be effective for severe KCS. However, it has been also emphasized that careful monitoring is mandatory in these cases because of steroid-related complications. ${ }^{87}$ Similar results were obtained from another study that evaluated the prevalence of long-term recurrence after topical nonpreserved methylprednisolone pulse therapy for the treatment of KCS with SS. ${ }^{88}$ In an experimental dry eye model, the mechanisms of topical methylprednisolone and doxycycline in the treatment of inflammation were described. ${ }^{59}$ According to that study, both agents reduced expression and activity of MMP-9, decreased levels of inflammatory cytokines transcripts and reduced activation of MAPKs in the corneal epithelium. ${ }^{59}$

Besides topical use, application systemic use should also be kept in mind in rare but severe KCS cases. ${ }^{89}$ However, because of its serious life-threatening systemic complications, other systemic immunosuppressive agents including methotrexate, $\mathrm{CsA}$, and infliximab may be required and tried in the treatment of recalcitrant primary and secondary SS caused by systemic autoimmune conditions to improve tear production. ${ }^{89}$

\section{Autologous and umbilical cord serum eye drops}

Recently, the use of both autologous and umbilical cord serum in the form of eye drops has been reported as an alternative treatment modality for severe ocular surface disorders in ophthalmic practice because of their components which include beneficial growth factors (ie, epidermal growth factor), vitamins (ie, vitamin A), and a number of antiinflammatory factors (ie, MMPs inhibitors such as TIMPs). ${ }^{2,90,91}$ Numerous studies have emphasized that the use of autologous ${ }^{92-94}$ and umbilical cord serum eye drops ${ }^{91,95}$ may provide satisfactory results in symptoms and objective signs of dry eye caused by severe SS, refractive surgery, and chronic GVHD.

\section{Tetracycline}

Despite its traditional antibiotic activity, tetracyclines have long been used for ocular surface inflammatory diseases since a number of antiinflammatory properties were discovered. As mentioned above, doxycycline, the semisynthetic tetracycline, was found to reduce expression and activity of MMP-9, decreased levels of inflammatory cytokines transcripts and reduced activation of MAPKs in the corneal epithelium in an experimental dry eye model. ${ }^{59}$ Similarly, another study by $\mathrm{Li}$ and colleagues also addressed that the efficacy of doxycycline which may be due to its ability to suppress the JNK and ERK MAPK signaling activation and inflammatory agents' production, which is so critical in the formation of inflammation induced by hyperosmolarity in human limbal epithelial cells. ${ }^{58}$ Tetracyclines have also been observed to suppress the steady state amounts of mRNA and protein of IL- $\beta$ and to decrease the bioactivity of this major inflammatory cytokine in the corneal epithelium. ${ }^{96}$ In ophthalmic practice, doxycyclines have been used in dry eye especially induced by acne rosacea and severe blepharitis. ${ }^{97,98}$

\section{Novel therapeutic agents}

Numerous research continues to establish new therapeutic agents for cases with dry eye, in addition to the agents explained above. For instance, one of the promising agents is the anti-CD4 monoclonal antibody that was found to suppress the local activation of $\mathrm{CD} 4+\mathrm{T}$ cells reducing the expansion of pathologic CD4+ T cells against $\alpha$-fodrin in a mouse model of SS. ${ }^{99}$ There are also a few studies suggesting that systemic linoleic and gamma-linolenic acids, and omega- 6 essential fatty acids may reduce the underlying ocular inflammation and in turn improve the signs and symptoms of ocular discomfort in KCS. ${ }^{100,101}$

The possible mechanisms, benefits and risks of the abovementioned agents are summarized in Table 1.

In conclusion, $\mathrm{KCS}$ is a multifactorial and complex disorder in which ocular surface, lacrimal gland, and lids are all involved in the pathogenesis. Taken together, all of the previously reviewed studies suggest that inflammation seems to play a critical role in the formation of dry eye and thereby current and novel antiinflammatory agents will continue to be an indispensable part of core treatment in addition to wetting with nonpreserved antifungal tears.

\section{Disclosure}

The authors were supported by research grant EY10738, EY from the Pearl Vision Foundation, Dallas, Texas, and an unrestricted grant from Research to Prevent Blindness, 
Table I Possible mechanisms, benefits, and risks of antiinflammatory agents used in the treatment of keratoconjunctivitis sicca

\begin{tabular}{|c|c|c|c|}
\hline Drugs & Possible mechanism & Benefits & Risks \\
\hline $\begin{array}{l}\text { Cyclosporine } \\
\text { ophthalmic } \\
\text { emulsion } \\
0.05 \%\end{array}$ & $\begin{array}{l}\text { - Mainly mediated by } \\
\text { immune cells } \\
\text { - Blocks the activa- } \\
\text { tion of JNK and p38 } \\
\text { signalling path- } \\
\text { ways during T cell } \\
\text { activation } \\
\text { - Inhibits the } \\
\text { phosphatase activity } \\
\text { of calcineurin }\end{array}$ & $\begin{array}{l}\text { - Satisfactory results in } \\
\text { patients with moderate } \\
\text { to severe keratocon- } \\
\text { junctivitis sicca } \\
\text { - Twice daily use } \\
\text { - Decreases the } \\
\text { necessity of frequent } \\
\text { use of artificial tears } \\
\text { and corticosteroids } \\
\text { - No significant topical } \\
\text { or systemic adverse } \\
\text { safety findings }\end{array}$ & $\begin{array}{l}\text { - Ocular burning } \\
\text { - Conjunctival hyper- } \\
\text { aemia, discharge, } \\
\text { epiphora, eye } \\
\text { pain, foreign body } \\
\text { sensation, pruritus, } \\
\text { stinging, and visual } \\
\text { disturbance (most } \\
\text { often blurring) }\end{array}$ \\
\hline Corticosteroids & $\begin{array}{l}\text { - Mainly mediated by } \\
\text { immune cells } \\
\text { - Reduce activation of } \\
\text { MAPKs } \\
\text { - Decrease levels } \\
\text { of inflammatory } \\
\text { cytokines }\end{array}$ & $\begin{array}{l}\text { - Well known agents } \\
\text { for many years } \\
\text { - Powerful antiinflam- } \\
\text { matory effect }\end{array}$ & $\begin{array}{l}\text { - Serious local } \\
\text { (glaucoma, cataract) } \\
\text { and systemic } \\
\text { adverse effects }\end{array}$ \\
\hline Tetracycline & $\begin{array}{l}\text { - Reduce MAPKs } \\
\text { in the cornea } \\
\text { epithelium } \\
\text { - Reduce expression } \\
\text { and activity of MMP9 } \\
\text { - Decrease levels of } \\
\text { inflammatory cytokines }\end{array}$ & $\begin{array}{l}\text { - Satisfactory results } \\
\text { in patients with acne } \\
\text { rosacea and severe } \\
\text { blepharitis }\end{array}$ & $\begin{array}{l}\text { - Systemic adverse } \\
\text { effects }\end{array}$ \\
\hline $\begin{array}{l}\text { Autologous/ } \\
\text { Umbilical cord } \\
\text { serum eye } \\
\text { drops }\end{array}$ & $\begin{array}{l}\text { - Contains beneficial } \\
\text { growth factors } \\
\text { (epidermal growth } \\
\text { factor), vitamins } \\
\text { (vitamin A) } \\
\text { - Contains a number } \\
\text { of antiinflammatory } \\
\text { factors (MMPs inhibi- } \\
\text { tors such as TIMPs) }\end{array}$ & $\begin{array}{l}\text { - Satisfactory results } \\
\text { in various causes of } \\
\text { keratoconjunctivitis } \\
\text { sicca }\end{array}$ & $\begin{array}{l}\text { - Difficulties in } \\
\text { formulation and } \\
\text { sterilization } \\
\text { - Serological problems }\end{array}$ \\
\hline $\begin{array}{l}\text { Anti CD4 } \\
\text { monoclonal } \\
\text { antibody }\end{array}$ & $\begin{array}{l}\text { - Suppress the local } \\
\text { activation of CD4+ } \\
\text { T cells }\end{array}$ & $\begin{array}{l}\text { - It is a promising } \\
\text { agent } \\
\text { - Since they have the } \\
\text { ability to bind very } \\
\text { specifically to their } \\
\text { target receptor, it is } \\
\text { possible to establish a } \\
\text { therapeutic strategy } \\
\text { with fewer side effects }\end{array}$ & $\begin{array}{l}\text { - Further } \\
\text { investigations are } \\
\text { needed to clarify its } \\
\text { efficacy and safety } \\
\text { in the treatment of } \\
\text { dry eye }\end{array}$ \\
\hline $\begin{array}{l}\text { Systemic } \\
\text { linoleic, } \\
\text { gamma- } \\
\text { linolenic acids, } \\
\text { omega-6 } \\
\text { essential fatty } \\
\text { acids }\end{array}$ & $\begin{array}{l}\text { - Has antiinflammatory } \\
\text { effects } \\
\text { - Acts directly on } \\
\text { T lymphocytes } \\
\text { - Reduces the expres- } \\
\text { sion of the inflamma- } \\
\text { tory marker HLA-DR } \\
\text { in conjunctival cells of } \\
\text { subjects with dry eye } \\
\text { - Increases the PGEI } \\
\text { levels in tears of } \\
\text { patients with SS }\end{array}$ & $\begin{array}{l}\text { - Could be of help } \\
\text { in controlling the } \\
\text { evolution of signs and } \\
\text { symptoms of dry eye } \\
\text { - Can be used with } \\
\text { other antiinflamma- } \\
\text { tory agents with lower } \\
\text { dosages thus reducing } \\
\text { the risks of the ocular } \\
\text { and systemic adverse } \\
\text { effects of antiinflam- } \\
\text { matory agents. }\end{array}$ & $\begin{array}{l}\text { - Further investiga- } \\
\text { tions are needed to } \\
\text { clarify its efficacy } \\
\text { and safety in the } \\
\text { treatment of dry eye }\end{array}$ \\
\hline
\end{tabular}

Abbreviations: MMP, matrix metalloproteinase; JNK, c-Jun NH2 terminal kinase; MAPKs, mitogen activated protein kinases; TIMP, tissue inhibitor of metalloproteinases; PGEI, prostaglandin EI. 
Inc., New York, New York. The authors report no conflicts of interest in this work.

\section{References}

1. Johnson ME, Murphy PJ. Changes in the tear film and ocular surface from dry eye syndrome. Prog Retin Eye Res. 2004;23:449-74.

2. Pflugfelder SC. Antiinflammatory therapy for dry eye. Am J Ohthalmol. 2004; $137: 337-42$.

3. Lemp MA. Report of the National Eye Institute/Industry workshop on clinical trials in dry eyes. CLAOJ. 1995;21:221-32.

4. McCarty CA, Bansal AK, Livingston PM, et al. The epidemiology of dry eye in Melbourne, Australia. Ophthalmology. 1998;105:1114-19.

5. Bjerrum KB. Keratoconjunctivitis sicca and primary Sjögren's syndrome in a Danish population aged 30-60 years. Acta Ophthalmol Scand. 1997;75:281-6.

6 Schein OD, Munoz B, Tielsch JM, et al. Prevalence of dry eye among the elderly. Am J Ophthalmol. 1997;124:723-8.

7. Moss SE, Klein R, Klein BE. Prevalence of and risk factors for dry eye syndrome. Arch Ophthalmol. 2000;118:1264-8.

8. Stern ME, Beuerman RW, Fox RI, et al. The pathology of dry eye: the interaction between the ocular surface and lacrimal glands. Cornea. 1998;17:584-9.

9. Gao J, Schwalb TA, Addeo JV, et al. The role of apoptosis in the pathogenesis of canine keratoconjunctivitis sicca: the effect of topical cyclosporin A therapy. Cornea. 1998;17:654-63.

10. Kunert KS, Tisdale AS, Stern ME, et al. Analysis of topical cyclosporine treatment of patients with dry eye syndrome: effect on conjunctival lymphocytes. Arch Ophthalmol. 2000;118:1489-96.

11. Stern ME, Gao J, Schwalb TA, et al. Conjunctival T-cell subpopulations in Sjögren's and non-Sjögren's patients with dry eye. Invest Ophthalmol Vis Sci. 2002;43:2609-14.

12. Zoukhri D. Effect of inflammation on lacrimal gland function. Exp Eye Res. 2006;82:885-98.

13. Fox RI. Pathogenesis of Sjögren's syndrome. Rheum Dis Clin North Am 1992;18:517-38

14. Fox RI. Sjögren's syndrome. Lancet. 2005;366:321-31.

15. Vitali C, Bombardieri S, Jonsson R, et al. Classification criteria for Sjögren's syndrome: a revised version of the European criteria proposed by the American-European Consensus Group. Ann Rheum Dis 2002;61:554-8.

16. Chen Q, Li X, He W, et al. The epitope study of alpha-fodrin autoantibody in primary Sjögren's syndrome. Clin Exp Immunol. 2007; 149:497-503.

17. Bacman S, Perez Leiros C, Sterin-Borda L, et al. Autoantibodies against lacrimal gland M3 muscarinic acetylcholine receptors in patients with primary Sjögren's syndrome. Clin Exp Immunol. 1996;104:454-9.

18. Routsias JG, Tzioufas AG. Sjögren's syndrome-study of autoantigens and autoantibodies. Clin Rev Allergy Immunol. 2007;32:238-51.

19 Manoussakis MN, Tzioufas AG, Pange PJE, et al. Serologic profiles in subgroups of patients with Sjögren's syndrome. Scand J Rheumatol. 1986;61:89-92.

20. Yavuz S, Toker E, Bicakcigil M, et al. Comparative analysis of autoantibodies against a-fodrin $\mathrm{n}$ serum, tear fluid, and saliva from patients with Sjögren's syndrome. J Rheumatol. 2006;33:1289-92.

21. Witte T, Matthias T, Bierwirth J, et al. Antibodies against alpha-fodrin are associated with sicca syndrome in the general population. Ann NY Acad Sci. 2007;1108:414-17.

22. Tilch DA, Schäfer HG, Winter R. Diagnostics of Sjögren's syndrome by means of anti-alpha-fodrin antibody. Klin Monatsbl Augenheilkd. 2007;224:427-30

23. Toker E, Yavuz S, Direskeneli H. Anti-Ro/SSA and anti-La/SSB autoantibodies in the tear fluid of patients with Sjögren's syndrome. Br J Ophthalmology. 2004;88:384-7.

24. Bacman S, Berra A, Sterin-Borda L, et al. Muscarinic acetylcholine receptor antibodies as a new marker of dry eye Sjögren syndrome. Invest Ophthalmol Vis Sci. 2001;42:321-7.
25. Waterman SA, Gordon TP, Rischmueller M. Inhibitory effects of muscarinic receptor autoantibodies on parasympathetic neurotransmission in Sjögren's syndrome. Arthritis Rheum. 2000;43:1647-54.

26. Beauregard C, Brandt PC, Chiou GC. Induction of nitric oxide synthase and over-production of nitric oxide by interleukin-1beta in cultured lacrimal gland acinar cells. Exp Eye Res. 2003;77:109-14.

27. Beauregard C, Brandt P. Down regulation of interleukin-1beta-induced nitric oxide production in lacrimal gland acinar cells by sex steroids. Curr Eye Res. 2004;29:59-66.

28. Zoukhri D, Macari E, Choi SH, et al. c-Jun NH2-terminal kinase mediates interleukin-1beta-induced inhibition of lacrimal gland secretion. J Neurochem. 2006;96:126-35.

29. Jones NP. Sarcoidosis. Curr Opin Ophthalmol. 2002;13:393-6.

30. Baughman RP, Lower EE, du Bois RM. Sarcoidosis. Lancet. 200;361:1111-18

31. Prabhakaran VC, Saeed P, Esmaeli B, et al. Orbital and adnexal sarcoidosis. Arch Ophthalmol. 2007;125:1657-62.

32. Heiligenhaus A, Wefelmeyer E, Schrenk M. Tear-film deficiencies in patients with sarcoidosis; clinical study of 56 patients. Klin Monatsbl Augenheilkd. 2002;219:502-6.

33. Margolis R, Lowder CY. Sarcoidosis. Curr Opin Ophthalmol. 2007;18:470-5.

34. Zissel G, Prasse A, Müller-Quernheim J. Sarcoidosis - immunopathogenetic concepts. Semin Respir Crit Care Med. 2007;28:3-14.

35. Takeuchi M, Oh-I K, Suzuki J, et al. Elevated serum levels of CXCL9/ monokine induced by interferon-gamma and CXCL10/interferongamma-inducible protein-10 in ocular sarcoidosis. Invest Ophthalmol Vis Sci. 2006;47:1063-8.

36. Hata M, Sugisaki K, Miyazaki E, et al. Circulating IL-12 p40 is increased in the patients with sarcoidosis, correlation with clinical markers. Intern Med. 2007;46:1387-93.

37. Agostini C, Meneghin A, Semenzato G. T-lymphocytes and cytokines in sarcoidosis. Curr Opin Pulm Med. 2002;8:435-40.

38. Baughman RP, Iannuzzi M. Tumour necrosis factor in sarcoidosis and its potential for targeted therapy. BioDrugs. 2003;17:425-31.

39. Dai H, Guzman J, Chen B, et al. Production of soluble tumor necrosis factor receptors and tumor necrosis factor-alpha by alveolar macrophages in sarcoidosis and extrinsic allergic alveolitis. Chest. 2005;127:251-6.

40. Kansu E. The pathophysiology of chronic graft-versus-host disease. Int J Hematol. 2004;79:209-15.

41. Ichiki Y, Bowlus CL, Shimoda S, et al. T cell immunity and graft-versus-host disease (GVHD). Autoimmun Rev. 2006;5:1-9.

42. Ogawa Y, Kuwana M. Dry eye as a major complication associated with chronic graft-versus-host disease after hematopoietic stem cell transplantation. Cornea. 2003;22:19-27.

43. Ogawa Y, Yamazaki K, Kuwana M, et al. A significant role of stromal fibroblasts in rapidly progressive dry eye in patients with chronic GVHD. Invest Ophthalmol Vis Sci. 2001;42:111-19.

44. Antin JH, Ferrara JL. Cytokine dysregulation and acute graftversus-host disease. Blood. 1992;80:2964-8.

45. Moss SE, Klein R, Klein BE. Incidence of dry eye in an older population. Arch Ophthalmol. 2004;122:369-73.

46. Schaumberg DA, Sullivan DA, Buring JE, et al. Prevalence of dry eye syndrome among US women. Am J Ophthalmol. 2003;136:318-26.

47. Ríos JD, Horikawa Y, Chen LL, et al. Age-dependent alterations in mouse exorbital lacrimal gland structure, innervation and secretory response. Exp Eye Res. 2005;80:477-91.

48. Draper CE, Adeghate E, Lawrence PA, et al. Age-related changes in morphology and secretory responses of male rat lacrimal gland. J Auton Nerv Syst. 1998;69:173-83.

49. Baudouin C. The pathology of dry eye. Surv Ophthalmol. 2001;45(Suppl 2):211-20.

50. Corrales RM, Villarreal A, Farley W, et al. Strain-related cytokine profiles on the murine ocular surface in response to desiccating stress. Cornea. 2007;26:579-84. 
51. Li DQ, Pflugfelder SC. Matrix metalloproteinases in corneal inflammation. Ocul Surf. 2005;3(Suppl 4):198-202.

52. Nakamura S, Shibuya M, Nakashima H, et al. Involvement of oxidative stress on corneal epithelial alterations in a blink-suppressed dry eye. Invest Ophthalmol Vis Sci. 2007;48:1552-8.

53. Solomon A, Dursun D, Liu Z, et al. Pro- and anti-inflammatory forms of interleukin-1 in the tear fluid and conjunctiva of patients with dry-eye disease. Invest Ophthalmol Vis Sci. 2001;42:2283-92.

54. Cejková J, Ardan T, Simonová Z, et al. Nitric oxide synthase induction and cytotoxic nitrogen-related oxidant formation in conjunctival epithelium of dry eye (Sjögren's syndrome). Nitric Oxide. 2007;17:10-7.

55. Paul A, Wilson S, Belham CM, et al. Stress-activated protein kinases: activation, regulation and function. Cell Signal. 1997;9:403-10.

56. Pflugfelder SC, de Paiva CS, Tong L, et al. Stress-activated protein kinase signaling pathways in dry eye and ocular surface disease. Ocul Surf. 2005;3(Suppl 4):154-7.

57. Luo L, Li DQ, Doshi A, et al. Experimental dry eye stimulates production of inflammatory cytokines and MMP-9 and activates MAPK signaling pathways on the ocular surface. Invest Ophthalmol Vis Sci. 2004;45:4293-301.

58. Li DQ, Luo L, Chen Z, et al. JNK and ERK MAP kinases mediate induction of IL-1beta, TNF-alpha and IL-8 following hyperosmolar stress in human limbal epithelial cells. Exp Eye Res. 2006;82:588-96.

59. De Paiva CS, Corrales RM, Villarreal AL, et al. Corticosteroid and doxycycline suppress MMP-9 and inflammatory cytokine expression, MAPK activation in the corneal epithelium in experimental dry eye. Exp Eye Res. 2006;83:526-35.

60. Gipson IK, Argüeso P. Role of mucins in the function of the corneal and conjunctival epithelia. Int Rev Cytol. 2003;231:1-49.

61. Gipson IK, Hori Y, Argüeso P. Character of ocular surface mucins and their alteration in dry eye disease. Ocul Surf. 2004;2:131-48.

62. Danjo Y, Watanabe H, Tisdale AS, et al. Alteration of mucin in human conjunctival epithelia in dry eye. Invest Ophthalmol Vis Sci. 1998;39:2602-9.

63. Sommer A. Effects of vitamin A deficiency on the ocular surface. Ophthalmology. 1983;90:592-600.

64. van Setten GB, Viinikka L, Tervo T, et al. Epidermal growth factor is a constant component of normal human tear fluid. Graefes Arch Clin Exp Ophthalmol. 1989;227:184-7.

65. McCulley JP, Shine WE. Meibomian gland function and the tear lipid layer. Ocul Surf. 2003;1:97-106.

66. Shine WE, McCulley JP. Keratoconjunctivitis sicca associated with meibomian secretion polar lipid abnormality. Arch Ophthalmol. 1998;116:849-52.

67. Lobefalo L, D'Antonio E, Colangelo L, et al. Dry eye in allergic conjunctivitis: role of inflammatory infiltrate. Int J Immunopathol Pharmacol. 1999; 12:133-7.

68. Greiner JV, Peace DG, Baird RS, et al. Effects of eye rubbing on the conjunctiva as a model of ocular inflammation. Am J Ophthalmol. 1985; 100:45-50.

69. Nussenblatt RB, Palestine AG. Cyclosporin: immunology, pharmacology, and therapeutic uses. Surv Ophthalmol. 1986;31:159-69.

70. Coster DJ, Shepherd WF, Fook TC, et al. Prolonged survival of corneal allografts in rabbits treated with cyclosporine A. Lancet. 1979;2:688-9.

71. Holland EJ, Olsen TW, Ketcham JM, et al. Topical cyclosporine A in the treatment of anterior segment inflammatory disease. Cornea. 1993;12:413-9.

72. Sahin A, Bozkurt B, Irkec M. Topical cyclosporine A in the treatment of superior limbic keratoconjunctivitis: a long-term follow-up. Cornea. 2008;27:193-5.

73. Matsuda S, Koyasu S. Mechanisms of action of cyclosporine. Immunopharmacology. 2000;47:119-25.

74. Djalilian AR, Nagineni CN, Mahesh SP, et al. Inhibition of inflammatory cytokine production in human corneal cells by dexamethasone, but not cyclosporin. Cornea. 2006;25:709-14.
75. Matsuda S, Shibasaki F, Takehana K, et al. Two distinct action mechanisms of immunophilin-ligand complexes for the blockade of T-cell activation. EMBO Rep. 2000;1:428-34.

76. Yoshida A, Fujihara T, Nakata K. Cyclosporin A increases tear fluid secretion via release of sensory neurotransmitters and muscarinic pathway in mice. Exp Eye Res. 1999;68:541-6.

77. Tatlipinar S, Akpek EK. Topical cyclosporin in the treatment of ocular surface disorder. Br J Ophthalmol. 2005;89:1363-7.

78. Gunduz K, Ozdemir O. Topical cyclosporin treatment of keratoconjunctivitis sicca in secondary Sjögren's syndrome. Acta Ophthalmol (Copenh). 1994;72:438-42.

79. Sall KN, Cohen SM, Christensen MT, et al. An evaluation of the efficacy of a cyclosporine-based dry eye therapy when used with marketed artificial tears as supportive therapy in dry eye. Eye Contact Lens. 2006;32:21-6.

80. Salib GM, McDonald MB, Smolek M. Safety and efficacy of cyclosporine $0.05 \%$ drops versus unpreserved artificial tears in dry-eye patients having laser in situ keratomileusis. J Cataract Refract Surg. 2006;32:772-8.

81. Sall K, Stevenson OD, Mundorf TK, et al. Two multicenter, randomized studies of the efficacy and safety of cyclosporine ophthalmic emulsion in moderate to severe dry eye disease.CsA Phase 3 Study Group. Ophthalmology. 2000;107:631-9.

82. Wang Y, Ogawa Y, Dogru M, et al. Ocular surface and tear functions after topical cyclosporine treatment in dry eye patients with chronic graft-versus-host disease. Bone Marrow Transplant. 2008;41:293-302.

83. Roberts CW, Carniglia PE, Brazzo BG. Comparison of topical cyclosporine, punctual occlusion, and a combination for the treatment of dry eye. Cornea. 2007;26:805-9.

84. Yen MT, Pflugfelder SC, Feuer WJ. The effect of punctal occlusion on tear production, tear clearance, and ocular surface sensation in normal subjects. Am J Ophthalmol. 2001;131:314-23.

85. Pflugfelder SC, Solomon A, Dursun D, et al. Dry eye and delayed tear clearance: "a call to arms". Adv Exp Med Biol. 2002;506:739-43.

86. Turner K, Pflugfelder SC, Ji Z, et al. Interleukin-6 levels in the conjunctival epithelium of patients with dry eye disease treated with cyclosporine ophthalmic emulsion. Cornea. 2000;19:492-6.

87. Marsh P, Pflugfelder SC. Topical nonpreserved methylprednisolone therapy for keratoconjunctivitis sicca in Sjögren syndrome. Ophthalmology. 1999;106:811-16.

88. Hong S, Kim T, Chung SH, et al. Recurrence after topical nonpreserved methylprednisolone therapy for keratoconjunctivitis sicca in Sjögren's syndrome. J Ocul Pharmacol Ther. 2007;23:78-82.

89. Cordero-Coma M, Anzaar F, Sobrin L, et al. Systemic immunomodulatory therapy in severe dry eye secondary to inflammation. Ocul Immunol Inflamm. 2007;15:99-104.

90. Geerling G, Maclennan S, Hartwig D. Autologous serum eye drops for ocular surface disorders. Br J Ophthalmol. 2004;88:1467-74.

91. Yoon KC, Heo H, Im SK, et al. Comparison of autologous serum and umbilical cord serum eye drops for dry eye syndrome. Am J Ophthalmol. 2007; 144:86-92.

92. Creuzot-Garcher C, Lafontaine PO, Brignole F, et al. [Treating severe dry eye syndromes with autologous serum]. J Fr Ophthalmol. 2004;27:346-51.

93. Ogawa Y, Okamoto S, Mori T, et al. Autologous serum eye drops for the treatment of severe dry eye in patients with chronic graft-versus-host disease. Bone Marrow Transplant. 2003;31:579-83.

94. Noda-Tsuruya T, Asano-Kato N, Toda I, et al. Autologous serum eye drops for dry eye after LASIK. J Refract Surgery. 2006;22:61-6.

95. Yoon KC, Im SK, Park YG, et al. Application of umbilical cord serum eyedrops for the treatment of dry eye syndrome. Cornea. 2006;25:268-72.

96. Solomon A, Rosenblatt M, Li DQ, et al. Doxycycline inhibition of interleukin-1 in the corneal epithelium. Invest Ophthalmol Vis Sci. 2000;41:2544-57.

97. Akpek EK, Merchant A, Pinar V, et al. Ocular rosacea: patient characteristics and follow-up. Ophthalmology. 1997;104:1863-7. 
98. Gilbard JP. Dry eye, blepharitis and chronic eye irritation: divide and conquer. J Ophthalmic Nurs Technol. 1999;18:109-15.

99. Hayashi Y, Ishimaru N, Arakaki R, et al. Effective treatment of a mouse model of Sjögren's syndrome with eyedrop administration of anti-CD4 monoclonal antibody. Arthritis Rheum. 2004;50:2903-10.
100. Barabino S, Rolando M, Camicione P, et al. Systemic linoleic and gamma-linolenic acid therapy in dry eye syndrome with an inflammatory component. Cornea. 2003;22:97-101.

101. Aragona P, Bucolo C, Spinella R, et al. Systemic omega-6 essential fatty acid treatment and pge1 tear content in Sjögren's syndrome patients. Invest Ophthalmol Vis Sci. 2005;46:4474-9. 
